\title{
Methacholine Chloride
}

National Cancer Institute

\section{Source}

National Cancer Institute. Methacholine Chloride. NCI Thesaurus. Code C47607.

The chloride salt form of methacholine, a direct-acting cholinergic muscarinic agonist with bronchoconstrictive, miotic, vasodilator, and cardiac vagomimetic activity.

Methacholine chloride acts directly on the muscarinic receptors in the heart, eye, and lung, thereby producing parasympathomimetic effects. 